\title{
SERODIAGNOSIS OF Xanthomonas campestris pv. sesami CAUSING BACTERIAL LEAF BLIGHT DISEASE IN SESAME
}

\author{
M. Inam-ul-Haq ${ }^{1,}$, Syeda Farah Naqvi', M. Ibrahim Tahir ${ }^{1}$, Hafiz Mujeebur Rehman ${ }^{2}$, Raees \\ Ahmed ${ }^{1}$ and Zahid Ali ${ }^{3}$ \\ ${ }^{1}$ Department of Plant Pathology, PMAS-Arid Agriculture University Rawalpindi, Pakistan; \\ ${ }^{2}$ Water Management Research Institute, Lahore, Pakistan; ${ }^{3}$ Department of Biosciences, COMSATS Institute of \\ Information Technology, Islamabad, Pakistan \\ "Corresponding author's e-mail: dr.inam@uaar.edu.pk
}

\begin{abstract}
Sesame is an important crop that has potential to add to edible oil production of Pakistan but bacterial blight incited by Xanthomonas campestris pv. sesami (Xcs) is most serious and devastating disease of sesame responsible for colossal losses. For decision of effective management strategy, proper identification of pathogen is pre-requisite. Present study was designed to evaluate ELISA with polyclonal antibodies (PAbs) for detection of Xcs with a fact that ELISA is cost effective and can be used for screening of large samples. PAbs were prepared in rabbits against pure isolate of Xcs. Direct antigen coated (DAC)ELISA was used for the analysis of pathogen in sesame germplasm obtained from NARC (Islamabad). Pathogen from 29 sesame varieties, categorized from resistant to susceptible, was isolated and used as an antigen. After incubation, OD was calculated at $405 \mathrm{~nm}$ and results revealed that lowest reaction (0.068) was observed in highly resistant sesame genotypes i.e. SG-22 and SG-55. While varieties SG-34, SG-33 and SG-72 were categorized as resistant based on reactivity (0.073). Thus it is concluded that ELISA with PAbs should be preferred for detection of Xcs because of the fact that they are more stable, target multiple epitopes on single antigen and are easy to produce.
\end{abstract}

Keywords: Serodiagnosis, blight, polyclonal antibodies (PAbs), (DAC)-ELISA, sesame germplasm

\section{INTRODUCTION}

Bacterial blight caused by Xanthomonas campestris pv. sesami has been one of the dominant diseases of sesame in Pakistan (Naqvi et al., 2012). The attack of the disease effects the production considerably with a fact that sesame is already cultivated on small area in Pakistan and the pathogen contributes to incapability of seed to germinate or slows down the seed germination and growth (Rehman et al., 2013). X. campestris is not only the major pathogen in sesame but it also has several other hosts where it causes substantial losses in yield (Hayward, 1993).

For selection of suitable management practices, accurate identification of plant pathogens is pre-requisite. For bacteria, though several detection methods (serological and nucleic acid based techniques) have been worked out of which PCR is the most reliable and efficient but the developing countries don't have enough resources and skills to employ such an expensive technique for large number of samples and thus cost effective, efficient method has to be employed and optimized. Enzyme linked immunosorbent assay (ELISA) is amenable for automation and often reproducible results have been obtained. The sensitivity of ELISA tests $\left(10^{3}-10^{6} \mathrm{cfu} / \mathrm{ml}\right)$ have been found sufficient in bacterial pathogens in symptomatic plants as well as in asymptomatic plants. ELISA based detection kits have been developed by Agdia, Inc.,
Bioreba etc. for several plant and animal pathogens with major focus on virus and bacteria (Narayanasamy, 2011). ELISA has been used for successful detection of several plant pathogenic bacteria e.g. Clavibacter michiganensis subsp. michiganensis $(\mathrm{Cmm}), \mathrm{X}$. axonopodis pv. vesicatoria $(\mathrm{Xcv})$ (Alvarez, 2004), X. campestris pv. oryzae (Zhu et al., 1998), $X$. axonopodis pv. citri (Permar and Gottwald, 1989), Clavibacter xyli subsp. xyli (Viswanathan, 1997), Ralstoniasolanacearum (Shan et al., 1997), Acidovorax avenae subsp. avenae (Aaa) (Zia-ul-Hussnain et al., 2013), X. campestris pv. musacearum (Xcm) (Nakato et al., 2013).

The specificity of detection of viruses and bacteria by wellknown serological techniques such as immunofluorescence (IF) and ELISA has improved greatly with the use of specific monoclonal and recombinant antibodies. Both allow the selection of specific target epitopes to avoid false positives (Lopez et al., 2003). However, as compared to monoclonal antibodies (MAbs) polyclonal antibodies (PAbs) can be generated much more rapidly, at less expense, and with less technical skill than is required to produce MAbs (Lipman $e t$ al., 2005). PAbs generated against virulent strains of $R$. solanacearum in tomato were specific to tomato but not to virulent strains of chili or aubergine and reactivity was also correlated with degree of infection (Rajeshwari et al., 1998). ELISA being an economical and effective method in detection of pathogens has potential for reliable detection for 
unknown bacterial pathogen. The information for ELISA based detection of Xcs is scarce and this study was designed to detect the bacterial blight pathogen through production of PAbs specific to Xcs and also its applicability was evaluated by screening the available germplasm of Sesame.

\section{MATERIALS AND METHODS}

Preparation of antigen and antiserum: Polyclonal antibodies to Xcs were produced by the animal unit at National Institute of Health (N.I.H), Islamabad, Pakistan. Bacterial blight disease isolate SG-39 was streaked on yeast extract dextrose calcium carbonate agar (YDCA) medium. Single colonies were selected and grown on fresh YDCA for $48 \mathrm{~h}$ at $28 \pm 2{ }^{\circ} \mathrm{C}$. The bacterial cells were suspended in 0.01 M PBS, pH 7.2 and rotated at $1250 \mathrm{rpm}$ for 10 minutes at $4^{\circ} \mathrm{C}$. Pellets were suspended in $5 \mathrm{ml}$ sterilized PBS and re-centrifuged for 20 minutes at $1250 \mathrm{rpm}$ before re-suspending in $5 \mathrm{ml}$ sterilized PBS; this suspension was maintained as a stock. The suspension was sonicated for 15 minutes in a Yamato Brawn sonic-12 ultrasonic Sonicator (US PATENT NO 3, 6.8, 6.26). Merthiolate $(0.01 \%)$ was added to the sonicated suspension and suspensions were stored at $4^{\circ} \mathrm{C}$.

Immunization of rabbits: Adult New Zealand white rabbits were immunized for antiserum production. Each animal was labeled (A \& B) with an ear tag. A record for rabbit and their individual treatments maintained during ear (intravenous) injection and for bleeding.

The concentration of all immunogens was adjusted to $1 \mathrm{mg} / \mathrm{ml}$ in $0.02 \mathrm{M}$ phosphate buffer, $\mathrm{pH} 7.2$ and emulsified in the same volume of Freund's complete adjuvant. Disposable syringes were used for injections. Schedules for antisera development in rabbits followed the methods described by Hoben et al. (1994) (Table 1).

Bleeding rabbits: Rabbits were bled on a bleeding rack to obtain 20-50 ml blood from the ear. Blood was transferred to a sterile $50 \mathrm{ml}$ screw-cap test tube and allowed to clot for 2 hours at room temperature. The clot was separated from the wall of tube using a sterilized glass rod. The serum was stored overnight at $4{ }^{\circ} \mathrm{C}$ to complete separation from the clot. Purification was carried out by centrifugation at $5000 \mathrm{rpm}$ for 10 minutes. Merthiolate $(0.01 \%)$ was added to the antiserum and the preparation stored at $4{ }^{\circ} \mathrm{C}$ until required (Hoben et al., 1994).

Serological Tests:

Gel immune diffusion tests: Two dimensional immunodiffusion tests (Ouchterlony, 2010) were performed in Petri dishes containing $12.5 \mathrm{ml} 0.75 \%$ agar in PBS $(0.02 \mathrm{M}, \mathrm{pH}$ 7.6), with $0.02 \%$ sodium azide. Fifteen microliter diluted or undiluted antigen and antiserum were charged into $3 \mathrm{~mm}$ diameter wells cut into the agar using a cork borer, and spaced $3.5 \mathrm{~mm}$ between each well. Unless otherwise stated test antigen consisted sonicated bacteria (Tomlinson and Walkey, 1967) which diffused satisfactorily through the agar gel.
Ultra-sonic fragmentation of bacteria $(0.5-1 \mathrm{mg} / \mathrm{ml})$ was carried out using either in the Bransonic laboratory cleaning unit for 15 minutes or a titanium probe for ten minutes at 1.5 amps. Dishes were incubated at $25 \pm 2{ }^{\circ} \mathrm{C}$ and observed for the agglutination reaction after 3-5 days by placing the dishes on an illuminated box. Photographs were taken after five days incubation.

Extracts from leaves of healthy sesame plants were used as control test antigens and normal rabbit serum as control test sera.

Table 1. Immunization schedules for stimulating antibody production in rabbit.

\begin{tabular}{ccc}
\hline Days & Injection Route & Amount of Antigen \\
\hline 1 & IV & $1.0 \mathrm{ml}$ \\
2 & IV & $1.0 \mathrm{ml}$ \\
3 & IV & $1.0 \mathrm{ml}$ \\
4 & IV & $1.5 \mathrm{ml}$ \\
5 & IV & $1.5 \mathrm{ml}$ \\
6 & IV & $2.0 \mathrm{ml}$ \\
7 & IV & $2.0 \mathrm{ml}$ \\
8 & IV & $1.5 \mathrm{ml}$ \\
9 & IV & $2.0 \mathrm{ml}$ \\
10 & IV & $2.0 \mathrm{ml}$ \\
\hline
\end{tabular}

Tube precipitation tests: In tube precipitation tests (Matthews, 1957) two fold dilutions of antiserum were prepared in PBS, pH 7.6, containing 0.14 M sodium chloride. Tubes having $0.5 \mathrm{ml}$ each of antigen and antiserum were incubated at $37 \pm 1^{\circ} \mathrm{C}$ for $2 \mathrm{hrs}$, left overnight at $4^{\circ} \mathrm{C}$ and the precipitates were observed in reflected light against a dark background.

Agglutination in micro titer plates: This test was performed after preparation of antiserum of rabbit (A \& B) to determine the true titer. Antiserum was diluted to 1:1024 in saline and titrated against one dilution of antigen. All wells in the microtiter plate were sealed with cellophane. The plate was incubated by floating in a water bath at $52^{\circ} \mathrm{C}$ for $4 \mathrm{hrs}$ and held overnight at $4^{\circ} \mathrm{C}$.

Titer calculation: To calculate the antibody titer, the highest dilution of serum at which positive agglutination occurred was multiplied by two to account for the equal volumes of diluted serum and antigen in the wells.

Preparation of IgG from Antisera: Antiserum (100 $\mu \mathrm{l})$ was transferred to a microanalysis tube of $500 \mu \mathrm{l}$ volume and $4 \mathrm{M}$ ammonium sulphate was added 10 times with each volume of $20 \mu \mathrm{l}$ and mixed thoroughly after the addition of each $20 \mu \mathrm{l}$. $\mathrm{pH}$ was adjusted to 7.8 by addition of $0.5 \mu \mathrm{l}$ of $1 \mathrm{~N}$ sodium hydroxide. The solution was left for $1 \mathrm{~h}$ at room temperature with occasional mixing and then centrifuged (4000-6000 rpm) for $5 \mathrm{~min}$. The supernatant was carefully removed and discarded while the pellet was re-suspended in $100 \mu \mathrm{l}$ of sterilized distilled water. Following this, it was dialyzed overnight with $400 \mathrm{ml}$ of $0.02 \mathrm{M} \mathrm{PBS}(\mathrm{pH} 7.8)$ after transferring to small dialysis chamber. The mixture was 
removed from dialysis chamber and volume was made up to $200 \mu \mathrm{l}$ with water. Glycerol $(100 \mu \mathrm{l})$ was added to make 30 percent $\mathrm{v} / \mathrm{v}$ mixtures and stored at $4^{\circ} \mathrm{C}$ in $500 \mu \mathrm{l}$ screw cap tubes.

Evaluation of sesame germplasm by DAC-ELISA: A direct antigen coating ELISA (DAC-ELISA) method was used to analyze diseased sesame samples. Wells in the microtiter plates were coated with antigen to provide the target for the unconjugated specific antibody. The trapped antibody was detected by a secondary antibody after conjugation with an enzyme. Samples of leaf tissues were dissected, washed and kept on ice to prevent degradation by proteases. The cut tissues were placed in round bottom microfuge tubes and immersed in liquid nitrogen. Extraction buffer (100 mM Tris, pH 7.4, $150 \mathrm{mM} \mathrm{NaCl}, 1 \mathrm{mM}$ EGTA, $1 \mathrm{mM}$ EDTA, $1 \%$ Triton X-100, 0.5\% Sodium deoxycholate) $300 \mu 1$ was added to the tube and homogenized with homogenizer. Tubes were centrifuged for $20 \mathrm{~min}$ at $13000 \mathrm{rpm}$ at $4^{\circ} \mathrm{C}$ and placed the supernatant on ice, aliquot supernatant to a fresh, chilled tube and store samples at $-80^{\circ} \mathrm{C}$. Extracts of sesame tissues were dispensed $(200 \mu \mathrm{l} /$ well) and incubated at room temperature for $1 \mathrm{~h}$. Micro titration plates (96 wells) were washed 3-4 times with washing buffer (10 mM phosphate buffer $\mathrm{pH} 7.4$, $150 \mathrm{mM} \mathrm{NaCl}, 0.05 \%$ Tween 20) at 5 min intervals before adding $200 \mu \mathrm{l}$ of polyclonal antiserum. Enzyme conjugate secondary antibody $(200 \mu \mathrm{l})$ was then added and the plate incubated as described above. Following washing in buffer, $200 \mu \mathrm{l}$ of substrate was added to each well and, following incubation for $60 \mathrm{~min}$ at room temperature, the reaction stopped by the addition of $5 \mu \mathrm{l}$ of $3 \mathrm{M}$ sodium hydroxide. Color was evaluated visually and read at $405 \mathrm{~nm}$ in an ELISA reader.

Evaluation of germplasm by DAC-ELISA: DAC-ELISA was employed to analyze the pathogen serologically from germplasm obtained from NARC (Islamabad). Samples from 29 different sesame varieties (SG-22, SG-55, SG-34, SG-33, SG-72, SG-71, SG-63, SG-29, SG-16, SG-11, SG-62, SG-42, SG-27, SG-2, SG-43, SG-30, SG-8, SG-40, SG-18, SG-9, SG-32, SG-25, SG-31, SG-99, SG-21, SG-107, SG-26, SG19, SG-23) were collected and pathogen $(X c s)$ was isolated and purified. Subsequently suspensions of the bacteria were prepared and rotated for 10 minutes at $3000 \mathrm{rpm}$ and the supernatant was used directly as antigen by coating plates for DAC-ELISA (Viswanathan, 2004).

Isolates of Xcs from different sesame varieties were considered as antigen and applied to the microtiter plates @ $200 \mu \mathrm{l}$ per well (Viswanathan, 2004). To optimize the DACELISA, the antigen and antiserum concentrations were standardized at dilutions of 1:250 and 1:1000, respectively. After incubation at room temperature for 30 minutes, reaction strength was rated visually at room temperature. One hour after the addition of the enzyme substrate, optical density (OD) was measured on the ELISA reader at $405 \mathrm{~nm}$.

\section{RESULTS}

Interaction of antigen and antiserum: In the gel immunodiffusion test, a positive result was obtained with a homologous titer of 1:16, although when the bacterium was titrated against antigen in a tube precipitation test, the highest titer attained was 1:216.

Determination of the antibody titer for rabbits $A$ and $B$ is given in Table 2. The titer of rabbit A reached 600 after 17 days and was 1000 after 19 days. The final bleeding, 7 days after the last injection, gave a titer 3200. Positive agglutination appeared as granular clumps in a clear supernatant and was detected at 1/1600 dilution of the serum. Similarly, the antibody titer from rabbit B also reached 800 after 17 days. After 19 days the titer was 1400, but the rabbit died of anaphylactic shock three days after the last injection.

Table 2. Titer of antisera to the bacterium associated with bacterial blight disease of sesame.

\begin{tabular}{|c|c|c|c|}
\hline Rabbit & Injections(IV) & Days after $1^{\text {stinjection }}$ & Titer \\
\hline \multirow[t]{3}{*}{ A } & 1 & 17 & 600 \\
\hline & 10 & 19 & 1000 \\
\hline & 26 & 33 & 3200 \\
\hline \multirow[t]{2}{*}{ B } & 1 & 17 & 800 \\
\hline & 10 & 19 & 1400 \\
\hline
\end{tabular}

Evaluation of germplasm by DAC-ELISA: Xcs was simply and effectively detected and diagnosed using DAC-ELISA. The highest titer of the Xcs bacterium (1.352) was recorded in the highly susceptible sesame varieties (Table 3 ). The ideal

Table 3. Detection of $X c s$ by DAC-ELISA in sesame varieties in relation to relative resistance/susceptibility.

\begin{tabular}{lllccl}
\hline Sr. & Category & SymptomExpression & $\begin{array}{c}\text { Mean } \\
\text { ELISAReactio } \\
\text { n }\end{array}$ & $\begin{array}{c}\text { No. of } \\
\text { genotypes }\end{array}$ & Genotypes \\
\hline 1 & HighlyResistant & Asymptomatic & 0.068 & 2 & SG-22, SG-55 \\
2 & Resistant & Slight Symptomatic & 0.073 & 3 & SG-34, SG-33, SG-72 \\
3 & ModeratelyResistant & Symptomatic & 0.121 & 2 & SG-71, SG-63, \\
4 & Moderatelysusceptible & Clear symptoms & 0.531 & 4 & SG-29, SG-16, SG-11,SG-62 \\
5 & Susceptible & Severesymptoms & 0.928 & 13 & SG-42, SG-27, SG-2, SG-43, SG-30, SG-8, \\
& & & & & SG-40, SG-18, SG-9,SG-32, SG-25, SG- \\
& & & 1.352 & 5 & S1, SG-99 \\
6 & Highly susceptible & Very intense symptom & & & SG-107, SG-26,SG-19, SG-23 \\
\hline
\end{tabular}


dilutions of antigen, antiserum and enzyme conjugate were found to be $1: 250,1: 1000$ and $1: 1000$, respectively.

Table 4. DAC-ELISA, (OD) values.

\begin{tabular}{lcc}
\hline Test Antigen & $($ OD) value 405nm & Visual color \\
\hline Purified antigen & $0.940-1.363$ & ++++ \\
Infected tissue & $0.120-0.939$ & +++ \\
Healthy tissue & $0.071-0.072$ & - \\
Extraction buffer & $0.066-0.071$ & - \\
\hline
\end{tabular}

\section{DISCUSSION}

The study was intended to explore the applicability of ELISA in detection of Xcs which has been curse for sesame production not only in Pakistan but other countries of the world. The data presented indicated the utility of ELISA for detecting the presence or absence of pathogen and it also enables to quantify the pathogen in infected tissues as observed by the OD calculated in all varieties categorized as resistant to susceptible. The bacterial blight disease bacterium was easily detected by DAC-ELISA. In that exhibited clear symptoms of blight, ELISA clearly detected the presence of the pathogen, giving higher absorbance values in comparison to other varieties. Cultivars SG-71 and SG-63, which showed no symptoms of blight, gave weakly positive results for the presence of the bacterial blight pathogen when tested with the ELISA method. DAC-ELISA can, therefore, be used for the detection of $X$. campestris in sesame crop. Many earlier diagnosis techniques like grow out test, direct plating and liquid assay employed for the diagnosis of bacteria were not trustworthy in contrast to serodiagnostic methods (Schaad and White, 1974; Parashar and Sharma, 1984). Similar method of DAC-ELISA was used by Alvarez et al. (1991) and Malandrin and Samson (1999) and they also observed serologically that infected samples were exploited as antigen in DAC-ELISA for the diagnosis of Xanthomonas. DACELISA with polyclonal antibodies was employed by Nakato et al. (2013) for detection of X. campestris pv. musacearum $(\mathrm{Xcm})$ and they found its applicability even in asymptomatic plants and also the detection was also comparable to PCR and culture based detection techniques.

PAbs were preferred to MAbs because they are less expensive and can be generated much more rapidly, and with less technical skill than is required to produce MAbs (Zola, 1999). The monospecificity of MAbs may limit their usefulness and small changes in the structure of an epitope (e.g. as a consequence of genetic polymorphism, glycosylation or denaturation) markedly affect their function (Lipman et al., 2005). In contrast, because PAbs are heterogeneous and recognize a host of antigenic epitopes, the effect of change on a single or small number of epitopes is less likely to be significant (Lipman et al., 2005). PAbs are also more stable over a broad range of $\mathrm{pH}$ and salt concentrations, whereas MAbs can be highly susceptible to small changes in both
(Lipman et al., 2005). Nakato et al. (2013) used PAbs for detection of $X \mathrm{~cm}$ and also checked its cross reactivity with other bacteria like Escherichia coli, X. vasicola pv. vasculorum of maize and sugarcane or $X$. vasicola $\mathrm{pv}$. holcicola of sorghum and results showed that PAbs reacted specifically with $\mathrm{Xcm}$ but not with other bacteria.

Alvarez et al. (1991) prepared antiserum against $X$. campestris pv. campestris strain A249 which was used to determine antigenic similarities between Xanthomonas strains isolated from cabbage and other crucifers, lettuce, and onion from different locations and the quantitative data provided by this application of the ELISA technique suggested that it could be used to distinguish among closely related Xanthomonas pathovars and strains causing diseases of cabbage, other crucifers, lettuce, and onion.

The outcomes of the current analysis revealed that for the diagnosis of the bacterium, DAC-ELISA is an effective and reliable technique that can diagnose bacteria even when the pathogen is present in low numbers. Furthermore, ELISA can be used utilized to distinguish among closely related pathovars/strains. Though effective, ELISA has certain limits for detection of pathogens, specially its ineffectiveness when working with latent infections, which need to be worked out further for better results.

\section{REFERENCES}

Alvarez, A., A. Benedict, C. Mizumoto, L. Pollard and E. Civerolo. 1991. Analysis of Xanthomonas campestris pv. citri and X. c. citrumelo with monoclonal antibodies. Phytopathol. 81:857-865.

Alvarez, A.M. 2004. Integrated approaches for detection of plant pathogenic bacteria and diagnosis of bacterial diseases. Ann. Rev. Phytopathol. 46:339-366.

Hayward, A.C. 1993. The host of Xanthomonas, pp.51-54.In: J.G. Swings and E.L. Civerolo (eds.), Xanthomonas. Chapman \& Hall, London, United Kingdom.

Hoben, H., P. Somasegaran, N. Boonkerd and Y. Gaur. 1994. Polyclonal antisera production by immunization with mixed cell antigens of different rhizobial species. World J. Microbiol. Biotechnol. 10:538-542.

Lipman, N.S., L.R. Jackson, L.J. Trudel and F.W. Garcia. 2005. Monoclonal versus polyclonal antibodies: distinguishing characteristics, applications, and information resources. Institute Lab. Animal Res. J. 46:258-268.

Lopez, M.M., E. Bertolini, A. Olmos, P. Caruso, M.T. Gorris, P. Llop, R. Penyalver and M. Cambra. 2003. Innovative tools for detection of plant pathogenic viruses and bacteria. Int. Microbiol. 6:233-243.

Malandrin, L. and R. Samson. 1999. Serological and molecular size characterization of flagellins of Pseudomonas syringae pathovars and related bacteria. Syst.App.Microbiol. 22:534-545. 
Matthews, R.E.F. 1957. Plant Virus Serology. Cambridge University Press, London, UK.

Nakato, G.V., S.A. Akinbade, P.L. Kumar, R. Bandyopadhyay and F. Beed.2013. Development of ELISA for the detection of Xanthomonas campestris pv. musacearum, the causal agent of BXW: Banana Xanthomonas Wilt. In: G. Blomme, B. Vanlauwe and P.V. Asten (eds.), Banana systems in the humid highlands of Sub-Saharan Africa: enhancing resilience and productivity. CAB International, Wallingford, UK. pp.93-100.

Naqvi, S.F., M. Inam-ul-Haq, M.I. Tahir and S.M. Mughal. 2012. Screening of sesame germplasm for resistance against the bacterial blight caused by Xanthomonas campestris pv. sesami.Pak. J. Agri. Sci.49:131-134.

Narayanasamy, P. 2011. Microbial Plant Pathogens: Detection and disease diagnosis of bacterial and phytoplasmas pathogens, Vol. 2. Springer Science and Business Media, Coimbatore, India. pp.24-25.

Ouchterlony, O. 2010. Diffusion-in-gel methods for immunological analysis II (Part 1 of 4). Karger Publishers.

Parashar, R. and D. Sharma. 1984. Detection of Xanthomonas campestris pv. cyamopsidis in guar seed lots (cluster bean). Ind. Phytopathol.37:353-355.

Permar, T.A. and T.R. Gottwald. 1989. Specific recognition of a Xanthomonas campestris Florida citrus nursery strain by a monoclonal antibody probe in a microfiltration enzyme immunoassay. Phytopathol.79:780-783.

Rajeshwari, N., M.D. Shylaja, M. Krishnappa, H.S. Shetty, C.N. Mortensen andS.B. Mathur. 1998. Development of ELISA for the detection of Ralstonia solanacearum in tomato: its application in seed health testing. World J. Micro. Biotechnol. 14:697-704.
Rehman, I., F. Deeba, M.I.ul Haque and S.M.S. Naqvi. 2013. Inhibition of sesame seedling growth by Xanthomonas campestris pv. sesami culture secretions. J. Anim. Plant Sci. 23:1207-1210.

Schaad, N. and W.C. White. 1974. A selective medium for soil isolation and enumeration of Xanthomonascampestris. Phytopathol. 64:876-880.

Shan, Z.H., B.S. Liao, Y.J. Tan, D. Li, Y. Lei and M.Z. Shen. 1997. ELISA technique used to detect latent infection of groundnut by bacterial wilt (Pseudomonas solanacearum). Oilcrops China19:45-47.

Tomlinson, J. and D. Walkey. 1967. Effects of ultrasonic treatment on turnip mosaic virus and potato virus $\mathrm{X}$. Virology 32:267-278.

Viswanathan, R. 1997. Detection of ratoon stunting disease (RSD) bacterium by ELISA. Madras Agric. J. 84:374377.

Viswanathan, R. 2004. Serodiagnosis of Leifsonia xyli subsp. xyli causing ratoon stunting disease in sugarcane, pp.155173. In: G. Rao, S. Saumtally and P. Rott (eds.), Sugarcane Pathology, Vol. 3, Bacterial and Nematode Diseases.CAB International, Wallingford, UK.

Zhu, W.G., B. Yang, J.M. Chittoor, L.B. Johnson and F.F. White. 1998. AvrXa10 contains an acidic transcriptional activation domain in the functionally conserved $\mathrm{C}$ terminus. Mol. Plant-Microbe Int. 11:824-832.

Zia-Ul-Hussnain, S., C.A. Rauf, M.I. Haque, S. Afghan, T. Mukhtar, F. Naz, M.K.N. Shah and A. Shahazad. 2013. Comparison of DAC-ELISA and Tissue Blot Immunoassay for the detection of Acidovorax avenae subsp. avenae, causal agent of red stripe of sugarcane. J. Plant Pathol. Microb. 4:172.

Zola, H. 1999. Monoclonal Antibodies. BIOS Scientific Publishers, Oxford, UK. 